International Research Journal of Management, IT \& Social Sciences
Available online at https://sloap.org/journals/index.php/irjmis/
Vol. 6 No. 1, January 2019, pages: 70 77
ISSN: 2395-7492
https://doi.org/10.21744/irjmis.v6n1.584

\title{
Packaging Design for Banten
}

Wayan Suryasa $^{a}$

\section{Article history:}

Received: 5 July 2018

Accepted: 30 November 2018

Published: 21 January 2019

\section{Keywords:}

banten;

design;

labeling;

marketing;

product;

\begin{abstract}
Bebantenan or banten is a series of hand-made products arranged according to certain rules. It used by Hindu communities in Bali as offerings. The banten production can be a livelihood for some people in Bali. One of the villages wherein the community produces banten for commercial activities was Lukluk Village. The partner in this study was the bebantenan group namely Sekar Jepun. The study was conducted become a solution regarding the problems occurred. The target set was in accordance with the activity planned to get the solution offered. It was included the products produced well packaged, therefore, they last long, partners have a logo become a brand image. Based on the activities implementation, the targets achieved were partners having attractive and eye-catching packaging labels, as well as neat packaging. With good packaging, it was hoped the products produced by partners will last long. Based on an evaluation by partners, they stated that they obtained a lot of orders due to the canang produced was well packed. The activities that cannot be conducted was packaging design training. This happened due to the members of the group who understood the computer were not active anymore.
\end{abstract}

2395-7492@ Copyright 2019. The Author.

This is an open-access article under the CC BY-SA license (https://creativecommons.org/licenses/by-sa/4.0/) All rights reserved.

Author correspondence:

Suryasa, W,

STIKOM Bali, Department of Computer System, Denpasar, Indonesia

Author ID: 57200211897, Ph. +6281338734500

Email address: suryasa@stikom-bali.ac.id

\section{Introduction}

Bebantenan/canang (one form of upakara made from coconut milk as a means of offering Balinese people who are Hindus) is a promising industry in Bali. There are 105 canang traders managed by the Regional Market Company, Badung Regency in 2012. Every day Hindus in Bali use canang for their worship activities (Shinde, 2012). The use of canang and banten has even increased dramatically during holidays. In a family in Bali, the use of 10-150 canang in one worship service. Even in the development of independent industries, canang sales are currently not only done in traditional markets but also able to find in supermarkets. This shows that the canang industry and expense are promising industries if managed well. Until now, the banten production can be a livelihood for some people in Bali 
(Scheifinger, 2008). One of the villages wherein the community produces banten for commercial activities is Lukluk Village. Lukluk has located in Badung Regency approximately $15 \mathrm{~km}$ from Denpasar.

The fresh raw materials used by partners unlike flowers, seeds, various kinds of leaves, fruits, etc (Mazumdar \& Mazumdar, 2009). The raw material must be maintained when the banten is used. If the canang sold by partners contain wilted or decayed flowers, they will be difficult to sell. Likewise, for those who use fruits, if the fruit is used to rot (Tripathi \& Dubey, 2004), then the banten price will decrease. It has not been anticipated by the two partners with good packaging (Berns, 1981). If the banten is well packaged, the flowers used will last longer, as are fruits and other fresh ingredients.

Based on the situation analysis conducted, the problems faced by the Sekar Jepun group included (1) The partners have not packed their products properly. It was not being packaged well, it causes their banten production easily to rot. If the banten quality components used are rotten, then the banten price will decrease or not be easily sold (Khouja \& Park, 2003; Fishman \& Rob, 2002), especially for mass-produced items such as canang, daksina (means of cylindrical offerings made of old coconut leaves resembling a rounded place), etc. (2) The partners do not have the characteristics that become their brand image, such as logos, packaging, etc. The logo will be the hallmark of the two partners, without the characteristic. It will not make it easier for the community to remember the two partners.

\section{Materials and Methods}

The study was located in Banjar Tengah, Lukluk Village, Badung Regency, with a bebantenan group namely SekarJepun. The priority issue of partners is related to the packaging of their products. They do not package their products well so that the freshness does not last long. In general, the ingredients from partner products are flowers and fruits. If the quality of the banten component used is rotten, then the banten price will decrease or not be easily sold, especially for those banten produced in mass such as canang and daksina. They do not have the characteristics that become their brand image, such as logos, packaging, etc. The logo will be the hallmark of the two partners, without the characteristic. It will not make it easier for the community to remember the two partners.

Maher \& Barbrack (1984) \& Dehlendorf et al., (2017), the procedure for the study conducted i.e., counseling is done in a classic way, which is giving explanations to partners through images. Training is conducted with computer media on partners who have computer skills. To achieve output from activities and overcome partner problems, the activities to be carried out can be described. The problem included product is perishable and not to have a brand image. The solution activity included counseling about the importance of packaging and packaging design training (Spence \& Marzillier, 1981). The output is able to make independent designs, has packaging and logo. The training conducted was for Sekar Jepun members of the bebantenan group who were able to use computers actively. The total number of candidates is approximately three members. The method used is by training that is informal with private methods. This is done to accelerate the skills of each trainee. The public participation in this study is not present.

\section{Results and Discussions}

The outputs generated from this activity included (1) $1.50 \%$ of trainees in partners are able to design simple packaging independently. (2) Bebanten partners have a group logo, and packaging with a good design for banten, such as canang, daksina, etc. It is expected to be able to differentiate the products of the two partners with products from other groups and increase their selling power. Griffin \& Page (1993), the product packaging will help independent groups to maintain the quality of their products for a long time. Coupled with good design, it will increase the attractiveness of the community to buy the product. Packaging and logos will be intended for banten production such as canang and daksina. In addition, if packaged properly, canang products from both partners can be marketed in addition to traditional markets, namely supermarkets.

Suryasa, W. (2019). Packaging design for banten. International Research Journal of

Management, IT and Social Sciences, 6(1), 70-77.

https://doi.org/10.21744/irjmis.v6n1.584 
Table 1

Implementation achievement of community service activities

\begin{tabular}{|c|c|c|c|}
\hline Partner Problems & Activity plan & Target & Achievement \\
\hline $\begin{array}{l}\text { (1) Partners have not } \\
\text { packed their } \\
\text { products properly. } \\
\text { By not being } \\
\text { packaged well, it } \\
\text { causes the banten to } \\
\text { produce easily to rot. } \\
\text { (2) Partners do not have } \\
\text { the characteristics } \\
\text { that become their } \\
\text { brand image, such as } \\
\text { logos, packaging, } \\
\text { etc. }\end{array}$ & $\begin{array}{l}\text { (1) Counseling about } \\
\text { the importance of } \\
\text { packaging and } \\
\text { packaging design } \\
\text { training. } \\
\text { (2) Able to make } \\
\text { independent } \\
\text { designs, has } \\
\text { packaging and logo } \\
\text { as well as } \\
\text { publication in the } \\
\text { international } \\
\text { journal. }\end{array}$ & $\begin{array}{l}\text { (1) } 50 \% \text { of trainees in } \\
\text { partners are able to } \\
\text { design simple } \\
\text { packaging } \\
\text { independently. } \\
\text { (2) Bebanten partners } \\
\text { have a package } \\
\text { with a good design } \\
\text { as well as } \\
\text { publication in } \\
\text { international } \\
\text { journals or } \\
\text { international } \\
\text { seminars. }\end{array}$ & $\begin{array}{l}\text { (1) Training packaging } \\
\text { design cannot be } \\
\text { carried out because } \\
\text { group members who } \\
\text { are able to use } \\
\text { computers are not } \\
\text { active in the group. } \\
\text { (2) Partners have a good } \\
\text { packaging design } \\
\text { and draft scientific } \\
\text { articles have been } \\
\text { made. }\end{array}$ \\
\hline
\end{tabular}

The activity to the society has been conducted for three weeks. Starting with socialization activities is to provide good packaging assistance. The activities series are in the following table.

Table 2

Implementation of community service activities

\begin{tabular}{|c|c|}
\hline No & Activity \\
\hline 1 & $\begin{array}{l}\text { Counseling activity provides an explanation to partners about the importance of good } \\
\text { packaging design if you want to expand market share. Good packaging is also needed to } \\
\text { ensure long-lasting products. In the outreach activities present were three members. }\end{array}$ \\
\hline 2 & $\begin{array}{l}\text { Packaging design making label design was made with the help of Adobe Photoshop CS } 6 \text {. } \\
\text { During the manufacturing process, the design obtained two revisions from the Partner. } \\
\text { Revision I. The design given does not yet contain images of frangipani flowers (Sekar } \\
\text { Jepun), which are expected to be a characteristic of this antagonistic group. Revision II. The } \\
\text { telephone number listed is incorrect because the partner changed the telephone number }\end{array}$ \\
\hline 3 & $\begin{array}{l}\text { The packaging design results that are already appropriate are given and started to be used } \\
\text { by partners. }\end{array}$ \\
\hline
\end{tabular}

The packaging design provided is in accordance with Figure 1. In the picture, the design given is to the head of the bebantenan group, namely Mrs. I Gusti Nuratmi or commonly called Biang Ngurah. 


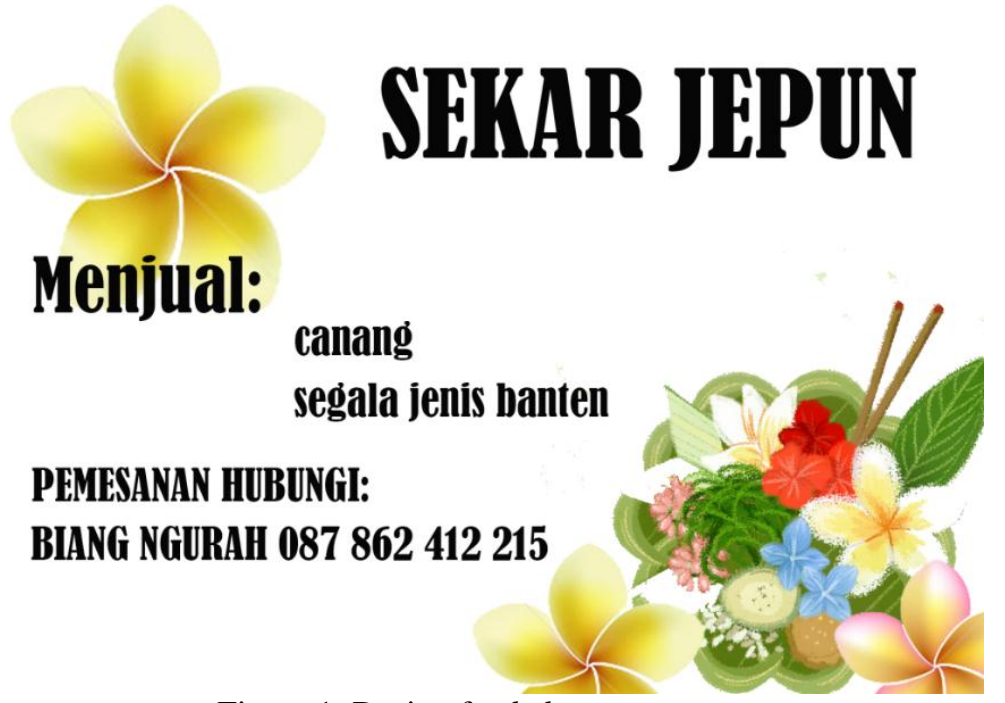

Figure 1. Design for bebantenan group

Description:

Sekar Jepun: Labelling

Menjual: Available

Canang: offerings for praying by Hindu

Segala jenis banten: all offerings items

Pemesanan hubungi: order contact person

Biang Ngurah: contact person name

Figure 2. Packaging design for banten canang bebantenan group of Sekar Jepun with the chairman of Biang Ngurah Group. The packaging results using the packaging label design are as follows:

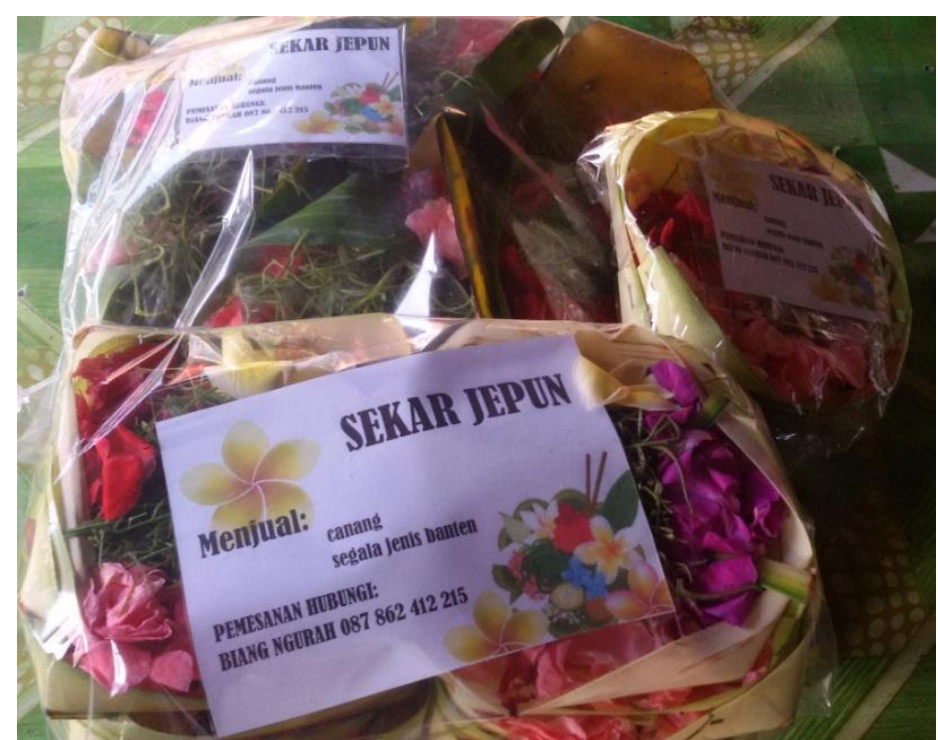

Figure 1. Packaging results 


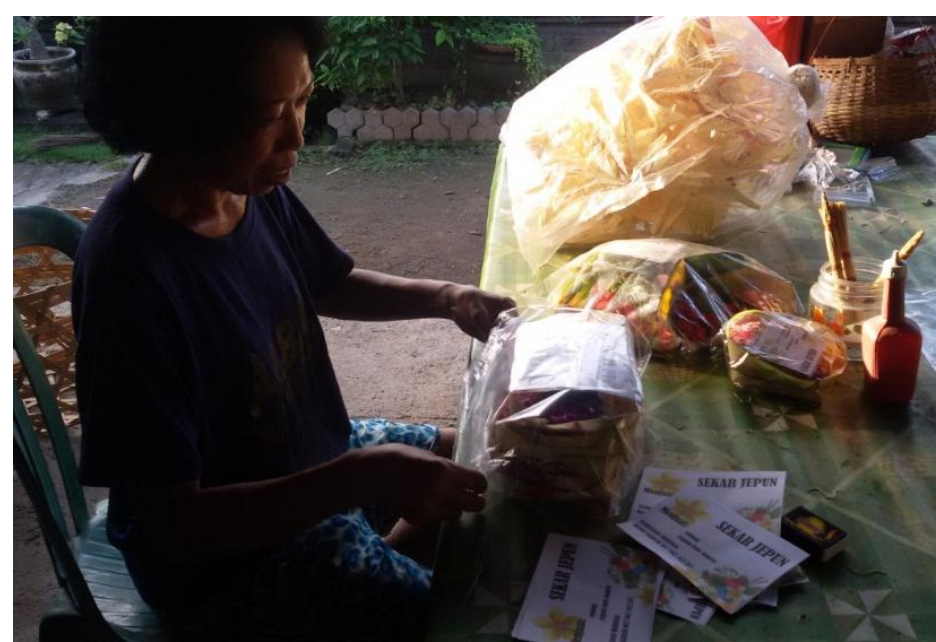

Figure 3. Packaging canang using a new label

\section{Activity Evaluation}

Internally, this activity did not reach the expected target, namely as many as 50\% of partners were able to design packaging independently. This cannot be achieved because packaging design training cannot be carried out because group members who are able to use computers are not active in the group. The solution to overcoming this problem is that the packaging label is given by the proposer. Based on the implementation of the activities, the partner's response to the overall activity is shown in Figure 3. The partner response to community service activities provided by Mrs. I Gusti Nuratmi as a chairman of the group stated that:

We were given a good packaging, therefore, some of the members that know computerization has been back to their village. the packaging is in accordance with our need as well as a suite packaging. It looks very cool. Many customers said that they will order more canang and daksina when the festival ceremony will become due to the products are better. We need more training about financial management.

Based on Figure 3, it is known that partners respond well to the activities that have been carried out. With the packaging design that has been provided, the partners mentioned that they obtained many orders because of the good packaging (Piqueras-Fiszman et al., 2012). They also stated that they would need financial management training and marketing assistance through social media (Facebook).

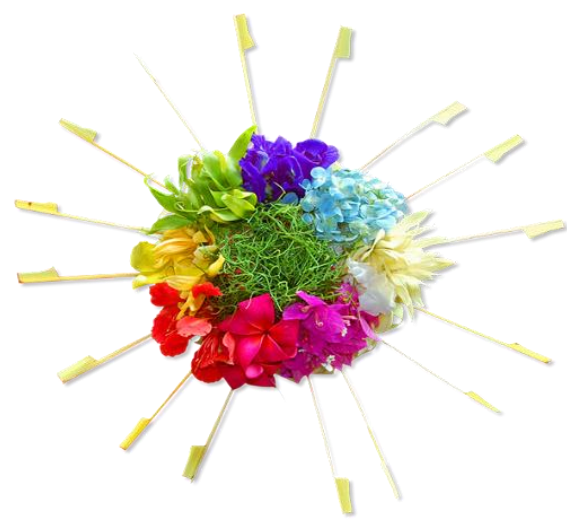

Figure 4. Canang

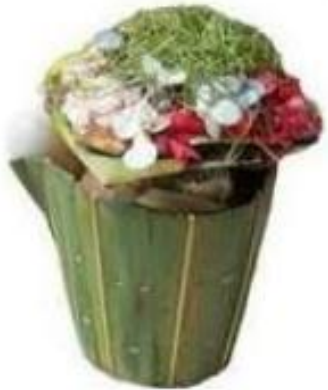

Figure 5. Daksina 


\section{Conclusion}

Based on the activities that have been conducted out, the conclusions obtained i.e., (1) Training cannot be carried out because members of partner groups who are able to use computers are already inactive in the bebantenan group. (2) Partners are given attractive and eye-catching packaging labels, so they can increase their sales. (3) Partners use good and attractive packaging so that the product lasts longer.

\section{Suggestion}

To avoid partner problems such as lack of human resources that control the computer can be done by providing basic computer knowledge first. In order for the packaging design process to be effective and efficient, cooperation between proposers and partners is needed. Good communication between partners and proposers will minimize the need for multiple revisions to the packaging design to be used.

Conflict of interest statement and funding sources

The author declared that he has no competing interest. The study was financed by STIKOM Bali.

Statement of authorship

The author has a responsibility for the conception and design of the study. The author has approved the final article.

Acknowledgments

This work was supported by the Research Fund provided by STIKOM Bali.

Suryasa, W. (2019). Packaging design for banten. International Research Journal of 


\section{References}

Berns, T. (1981). The handling of consumer packaging. Applied ergonomics, 12(3), 153-161. https://doi.org/10.1016/0003-6870(81)90004-1

Dehlendorf, C., Grumbach, K., Schmittdiel, J. A., \& Steinauer, J. (2017). Shared decision making in contraceptive counseling. Contraception, 95(5), 452-455. https://doi.org/10.1016/j.contraception.2016.12.010

Fishman, A., \& Rob, R. (2002). Product innovations and quality-adjusted prices. Economics letters, 77(3), 393-398. https://doi.org/10.1016/S0165-1765(02)00154-4

Griffin, A., \& Page, A. L. (1993). An interim report on measuring product development success and failure. Journal of product innovation management, 10(4), 291-308. https://doi.org/10.1016/0737-6782(93)90072-X

Khouja, M., \& Park, S. (2003). Optimal lot sizing under continuous price decrease. Omega, 31(6), 539-545. https://doi.org/10.1016/j.omega.2003.08.009

Maher, C. A., \& Barbrack, C. R. (1984). Evaluating the individual counseling of conduct problem adolescents: The goal attainment scaling method. Journal of School Psychology, 22(3), 285-297. https://doi.org/10.1016/00224405(84)90009-8

Mazumdar, S., \& Mazumdar, S. (2009). Religion, immigration, and home making in diaspora: Hindu space in Southern California. Journal of Environmental Psychology, 29(2), 256-266. https://doi.org/10.1016/j.jenvp.2008.07.004

Piqueras-Fiszman, B., Velasco, C., \& Spence, C. (2012). Exploring implicit and explicit crossmodal colour-flavour correspondences in product packaging. Food Quality and Preference, 25(2), 148-155. https://doi.org/10.1016/j.foodqual.2012.02.010

Scheifinger, H. (2008). Hinduism and cyberspace. Religion, 38(3), 233-249. https://doi.org/10.1016/j.religion.2008.01.008

Shinde, K. A. (2012). Place-making and environmental change in a Hindu pilgrimage site in India. Geoforum, 43(1), 116-127. https://doi.org/10.1016/j.geoforum.2011.07.014

Spence, S. H., \& Marzillier, J. S. (1981). Social skills training with adolescent male offenders-II. Short-term, longterm and generalized effects. Behaviour Research and Therapy, 19(4), 349-368. https://doi.org/10.1016/00057967(81)90056-5

Tripathi, P., \& Dubey, N. K. (2004). Exploitation of natural products as an alternative strategy to control postharvest fungal rotting of fruit and vegetables. Postharvest biology and Technology, 32(3), 235-245. https://doi.org/10.1016/j.postharvbio.2003.11.005 


\section{Biography of Author}

\begin{tabular}{l}
\hline I Wayan Suryasa, S.S., M.Hum. was born in Marga on July $5^{\text {th }}$, 1981. He graduated his \\
bachelor degree in the Faculty of Letter, Warmadewa University in 2006. He finished his \\
master degree in the postgraduate program, magister program, linguistic studies, \\
Udayana University in 2014. He currently is doing his dissertation at Udayana \\
University. He was the founder of the ScienceScholar institution in Tabanan. He lives at \\
Jalan Kubu Gunung, No. 81, Tegaljaya, Dalung, Badung - Bali. \\
Email: iwayansuryasa@gmail.com / iwayansuryasa@utm.edu.ec / suryasa@stikom- \\
bali.ac.id.
\end{tabular}

